UČESTALOST INFEKCIJA TOKOM PRIMENE VISOKODOZNE HEMIOTERAPIJE SA AUTOLOGNOM TRANSPLANTACIJOM MATIČNIH ĆELIJA

\title{
INCIDENCE OF INFECTIONS DURING THE APPLICATION OF HIGH-DOSE CHEMOTHERAPY WITH AUTOLOGOUS STEM CELL TRANSPLANTATION
}

\author{
1 Dom Zdravlja "Voždovac", Beograd, Srbija \\ 2 Klinika za hematologiju, Univerzitetski Klinički centar Srbije, \\ Beograd, Srbija \\ 3 Medicinski fakultet Univerziteta u Beogradu, Beograd, Srbija \\ 4 Institut za medicinsku statistiku i informatiku
}

Milica Milošević' , Jelena Bila ${ }^{2,3}$, Dejana Stanisavljevićc ${ }^{3,4}$, Milena Todorović Balint ${ }^{2,3}$

\section{SAŽETAK}

Uvod: Autologna transplantacija matičnih ćelija hematopoeze (ATMĆH) je standardni oblik lečenja hematoloških maligniteta. Promene u strategiji ATMĆH-a i unapređenje potporne nege značajno su smanjili incidenciju i obrazac ispoljavanja infekcija kod pacijenata.

Cilj rada: Ispitati učestalost infekcija u prvih 30 dana nakon ATMĆH-a, kao i eventualni uticaj broja CD34 matičnih ćelija u transplantatu i parametara engraftmenta: ALC500_20 (engl. absolute lymphocyte count 0,5x10\%/L na dan +20 ), ANC500_11 (engl. absolute neutrophil count 0,5x10\% /L na dan +11), i PLT20_13 (engl. platelets $20 \times 10^{9} / \mathrm{L}$ na dan +13 ), na pojavu infekcija.

Materijali i metode: $U$ retrospektivnoj kohortnoj studiji ispitivano je 80 bolesnika starosti iznad 20 godina sa dijagnozom multiplog mijeloma (MM), nehočkinskih limfoma (NHL) i Hočkinovog limfoma (HL), lečenih na Klinici za hematologiju Kliničkog centra Srbije, u periodu od jula 2006. do decembra 2017. godine. Zabeležene su sve epizode povišene telesne temperature i/ili dokumentovane infekcije u toku neutropenije.

Rezultati: Prosečno preživljavanje nakon ATMĆH-a iznosilo je 34,5 meseci, a kod 54 pacijenta $(67,5 \%)$ je dokumentovan uzročnik infekcije. Gram pozitivne bakterijske infekcije su bile pet puta češce u odnosu na gram negativne. Kod gram pozitivnih izolata najčešći je bio koagulaza negativni staphylococcus - CoNS (engl. coagulase-negative staphylococcus), 37,0\%, i Streptococcus a haemoliticus, 12,4\%. Među gram negativnim izolatima najčešća je bila Escherichia coli, 62,5\%, a Klebsiella spp. i Ralstonia pickettii su bile zastupljene sa podjednakom učestalošću od $12,5 \%$. Gljivične infekcije su bile retke (10,0\% Candida spp). Virusne infekcije su verifikovane kod 5 (6,3\%) pacijenata (Herpes zoster virus, 3,8\% i H1N1, 2,5\%).

Zaključak: Broj CD34+ matičnih ćelija u transplantatu, kao i brzina rekonstitucije hematopoeze, odnosno postizanje ALC500_20,_ANC500_11 i PLT20_13, nisu bili statistički značajni za nastanak infekcija u ranoj fazi nakon ATMĆH-a.

Ključne reči: autologna transplantacija matičnih ćelija, limfomi, multipli mijelom, infekcija

Autor za korespondenciju:

Milica Miloševic

Dom Zdravlja „Voždovac", Beograd, Srbija

Nikšićka 32/3, 11000 Beograd, Srbija

Elektronska adresa: milosevic.milica.12@gmail.com

Primljeno - Received: June 1, 2021; Revidirano - Revised: October 25, 2021;

\author{
Community Health Care Center "Voždovac", Belgrade, Serbia \\ 2 Clinic for Hematology, University Clinical Center of Serbia, \\ Belgrade, Serbia \\ 3 Faculty of Medicine, University of Belgrade, Belgrade, Serbia \\ 4 Institute of Medical Statistics and Informatics
}

\begin{abstract}
Introduction: Autologous stem cell transplantation (AHSCT) is a well-established therapy for hematologic malignancies. Changes in transplantation strategies and improvement in supportive care have significantly altered the incidence and pattern of infections in these patients.

Aim: Evaluating the frequency of infections in the first 30 days after AHSCT, as well as the possible influence of the number of CD34 + stem cells in the graft and of the engraftment parameters: ALC500_20 (absolute lymphocyte count $0.5 \times 10^{9}$ / L per day + 20), ANC500_11 (absolute neutrophil count $0.5 \times 10^{9} / \mathrm{L}$ per day +11 ), and PLT20_13 (platelets 20x10\% / L per day +13 ), on the occurrence of infections. Materials and methods: The retrospective cohort study examined 80 patients above the age of 20 years, diagnosed with multiple myeloma (MM), non-Hodgkin's (NHL) or Hodgkin's lymphoma (HL), treated at the Clinic for Hematology of the Clinical Center of Serbia, in the period between July 2006 and December 2017. All episodes of fever and/or documented infection during neutropenia have been reported. Results: The average survival after AHSCT was 34.5 months. A total of 54 patients (67.5\%) had a documented infection. Gram-positive infections were five times more common than gram-negative. In gram-positive isolates, coagulase-negative staphylococcus - CoNS was the most common (37.0\%) pathogen, followed by Streptococcus a haemolyticus (12.4\%). Among gram-negative isolates, Escherichia coli was present in $62.5 \%$ of the cases, while Klebsiella spp. and Ralstonia pickettii were represented with an equal frequency of $12.5 \%$. Fungal infections were rare (Candida spp., 10.0\%). Viral infections were verified in 5 (6.3\%) patients (Herpes zoster virus $3.8 \%$ and $\mathrm{H} 1 \mathrm{~N} 12.5 \%)$.
\end{abstract}

Conclusion: The number of CD34+ stem cells in the graft, as well as the rate of hematopoietic reconstitution, i.e., the achievement of ALC500_20, ANC500_11, and PLT20_13, were not statistically significant for the development of infections in the early phase after AHSCT.

Key words: autologous stem cell transplantation, lymphoma, multiple myeloma, infection

\section{Corresponding author:}

Milica Miloševic

Community Health Care Center Voždovac, Belgrade, Serbia

32/3 Nikšićka Street, 11000 Belgrade, Serbia

E-mail:milosevic.milica.12@gmail.com

Prihvaćeno • Accepted: October 31, 2021; Online first: December 13, 2021. 


\section{UVOD}

Autologna transplantacija matičnih ćelija hematopoeze (ATMĆH) predstavlja standardni pristup u lečenju hematoloških maligniteta. Glavne indikacije za ATMĆH su multipli mijelom i limfomi. U novije vreme, ovaj pristup pokazuje i sve veći potencijal u lečenju solidnih tumora, kao i nekih neuroloških i autoimunih oboljenja [1-4].

Praćenjem pacijenata u inicijalnoj fazi nakon transplantacije, dobijeni su podaci koji pokazuju da su infekcije značajan uzrok mortaliteta u 2,0\% slučaja. Infekcija se definiše kao izolacija ili detekcija patoloških mikroorganizma, asocirana sa simptomima bolesti [5] Uočeno je da, kod odraslih pacijenata, gram-pozitivne bakterijske infekcije (GP) prevazilaze broj infekcija izazvanih gram-negativnim bakterijama (GN), kao i da se bakterijemija javlja kod petine ispitanika [6-9]. Invazivne gljivične infekcije, najčešće Candida-om i Aspergillus-om, su neuobičajene [10]. Ukoliko se ipak jave, predstavljaju predominantne uzročnike u pre-engrafment fazi [11]. Trajanje neutropenije $\geq 10$ dana nakon ATMĆH-a, povezano je sa pojavom ranih infekcija nakon ATMĆ́H-a [12].

Osim podataka o infekcijama, u prvih nekoliko dana posle ATMĆH-a, treba uzeti u razmatranje i podatke o komplikacijama u toku prve godine nakon procedure, kao bitnu implikaciju dugogodišnjeg preživljavanja.

Najčešće virusne infekcije zahvataju respiratorni trakt i kožu, a posledice su reaktivacije Herpes zoster virusa. Prema Bartonu i Kolisu, tokom prve godine nakon ATMĆH-a, pacijenti imaju nizak rizik za smrtni ishod usled infekcija [5]. Tokom protekle dve decenije, učinjene su bitne izmene u strategiji lečenja, sa poboljšanjem antivirusne i antigljivične profilakse, što je dovelo do značajnih promena u incidenciji posttransplantacionih infekcija. Upotreba faktora rasta uz autolognu potporu matičnim ćelijama značajno je skratila trajanje neutropenije. Poznavanje same etiologije i učestalosti infekcija važno je za planiranje odgovarajuće strategije prevencije i njihovog empirijskog lečenja.

Cilj rada bilo je ispitivanje učestalosti infekcija u prvih 30 dana nakon ATMĆH-a, kao i eventualnog uticaja broja CD34 ${ }^{+}$matičnih ćelija u transplantatu i parametara engraftmenta: ALC500_20 (engl. absolute lymphocyte count $0,5 \times 10^{9} / \mathrm{L}$ na dan +20 ), ANC500_11 (engl. absolute neuthrophil count $0,5 \times 10^{9} / \mathrm{L}$ na dan +11$)$, i PLT20_13 (engl. platelets $20 \times 10^{9} / \mathrm{L}$ na dan +13 ), na pojavu infekcija.

\section{MATERIJALI | METODE}

$\mathrm{U}$ retrospektivnoj kohortnoj studiji ispitivano je 80 bolesnika starosti iznad 20 godina, sa dijagnozom multiplog mijeloma (MM), nehočkinskih limfoma $(\mathrm{NHL})$ i Hočkinovog limfoma $(\mathrm{HL})$, lečenih na Klinici za

\section{INTRODUCTION}

Autologous hematopoietic stem cell transplantation (AHSCT) represents the standard approach to the treatment of hematological malignancies. The main indications for AHSCT are multiple myeloma and lymphoma. As of late, this approach has shown a growing potential in the treatment of solid tumors, as well as in the treatment of some neurological and autoimmune diseases [1-4].

Patient follow-up, in the initial phase following transplantation, has provided data showing that infections are a significant cause of mortality in $2.0 \%$ of the cases. Infection is defined as the isolation and detection of pathological microorganisms, associated with symptoms of disease [5]. In adults, it has been detected that gram-positive bacterial infections (GP) outnumber the number of infections caused by gram-negative bacteria (GN), as well as that bacteriaemia occurs in one fifth of the subjects [6-9]. Invasive fungal infections, usually caused by Candida or Aspergillus, are unusual [10]. However, if they do occur, they are predominant causative agents in the pre-engraftment phase [11]. Duration of neutropenia $\geq 10$ days following AHSCT has been linked to early infections following AHSCT [12].

Apart from data on infections in the first few days following AHSCT, data related to complications during the first year following the procedure should be taken into consideration, as an important implication of long-term survival.

The most common viral infections include the respiratory tract and the skin, and are caused by the reactivation of the Herpes zoster virus. According to Barton and Collis, during the first two years following AHSCT, patients have low risk of a lethal outcome caused by infection [5]. Over the past two decades, significant changes have been made in treatment strategy, with improvements in antiviral and antifungal prophylaxis, which has led to significant changes in the incidence of post-transplant infections. The use of the growth factor with autologous stem cell support has significantly shortened the duration of neutropenia. The understanding of infection etiology and of the frequency of infection is important for planning the appropriate prevention strategy and for empirical treatment of infection.

The aim of this paper was analyzing the frequency of infections in the first 30 days following AHSCT, as well as investigating the possible influence of the number of $\mathrm{CD}_{34}{ }^{+}$stem cells in the graft and of the engraftment parameters: ALC500_20 (absolute lymphocyte count $0.5 \times 10^{9} / \mathrm{L}$ per day +20 ), ANC500_11 (absolute neuthrophil count $0.5 \times 10^{\%} / \mathrm{L}$ per day +11 ), and PLT20_13 (platelets $20 \times 10^{9} /$ L per day +13 ), on the occurrence of infections. 
Hematologiju Kliničkog centra Srbije (KCS), u periodu od jula 2006. do decembra 2017. godine.

\section{Mikrobiološke metode}

Nakon ATMĆH-a, infekcije su dijagnostikovane izolacijom uzročnika iz kulture tkiva (bakterije, gljivice), dokazivanjem gljivičnih antigena i antitela (gljivice), i tehnikom reakcije lančane polimeraze - PCR (virusi). Bakterijska infekcija podrazumeva bakterijemiju i/ili pozitivan bris kože i/ili sluznice. $U$ analizu su uključene samo infekcije koje su se pojavile 0 - 30 dana nakon transplantacije, u odsustvu komplikacija. Zabeležene su sve epizode povišene telesne temperature i/ili dokumentovane infekcije u toku neutropenije. Trajanje neutropenije se definiše kao vremenski period, izražen u danima, u kojem je broj neutrofila $<500 / \mathrm{mm}^{3}$, odnosno $<0,5 \times 10^{9} / \mathrm{L}$. Prema preporukama Američkog udruženja infektologa (engl. Infectious Diseases Society of America - IDSA), febrilnost se definise kao prva epizoda povišene temperature $>38,3^{\circ} \mathrm{C}$, ili temperatura $>38,0^{\circ} \mathrm{C}$, izmerena najmanje dva puta u toku 12 sati, i zahteva ponavljane kliničke preglede, radiografski snimak grudnog koša i laboratorijsku i mikrobiološku analizu periferne venske krvi [13]. Pozitivna mikrobiološka kultura smatra se značajnom, ukoliko nije naglašena slučajna kontaminacija uzorka. Dijagnoza koagulaza negativnog staphylococcus-a (CoNS) podrazumeva dve pozitivne mikrobiološke kulture. Za dijagnozu pneumonije, neophodno je prisustvo povišene temperature uz radiološki potvrđen nalaz na plućima. Uspešan odgovor na terapiju znači smanjenje telesne temperature $<37,5^{\circ} \mathrm{C}$, uz klinički vidljive znakove poboljšanja unutar prva 24 sata.

\section{Profilaksa}

Svi pacijenti su dobijali antivirusnu profilaksu - aciklovir, $2 \times 400$ mg p.o., 3 nedelje, u posttransplantacionom periodu. Kao antigljivična profilaksa primenjivan je flukonazol, $150 \mathrm{mg}$ p.o. do +30 dana (d) nakon transplantacije.

\section{Statistička obrada}

Za statističku obradu podataka korišćen je softver SPSS 17.0. Statistička obrada je obuhvatila formiranje baze podataka, sa grupisanjem i tabeliranjem rezultata po ispitivanim obeležjima bolesnika. Deskriptivni statistički parametri su izraženi kroz aritmetičku sredinu sa merama disperzije (standardna devijacija - SD, standardna greška - $S E$ ), medijanu, mod, i raspodelu relativnih frekvencija. Za procenu značajnosti razlike učestalosti posmatranih obeležja korišćen je hi-kvadratni test. Ukupno preživljavanje bolesnika je obuhvatalo period od momenta dijagnoze do smrtnog ishoda ili zaključno sa podacima iz decembra 2017. godine, kod

\section{MATERIALS AND METHODS}

In this retrospective cohort study, 80 patients older than 20 years, diagnosed with multiple myeloma (MM), non-Hodgkin lymphoma (NHL), or Hodgkin's lymphoma $(\mathrm{HL})$, treated at the Clinic for Hematology of the Clinical Center of Serbia (CCS), in the period between July 2006 and December 2017, were examined.

\section{Microbiology methods}

After AHSCT, infections were diagnosed by isolating the pathogens from tissue cultures (bacteria, fungi), by proving fungal antigens and antibodies (fungi), and with the technique of polymerase chain reaction $(P C R)$ (viruses). Bacterial infection exists when there is bacteremia and/ or a positive skin or mucosal swab result. Only infections occurring 0 to 30 days following transplantation, in the absence of complications, were included in the analysis. All episodes of elevated body temperature and/or documented infections during neutropenia were recorded. The duration of neutropenia is defined as the number of days during which the neutrophil count is $<500 / \mathrm{mm}^{3}$, i.e., $<0.5 \times 10^{9} / \mathrm{L}$. According to the Infectious Diseases Society of America (IDSA) guidelines, fever is defined as a single episode of elevated body temperature of $>38.3^{\circ} \mathrm{C}$, or body temperature of $>38.0^{\circ} \mathrm{C}$, measured at least twice in the space of 12 hours, and it requires repeated clinical examinations, radiographic imaging of the thorax, and laboratory and microbiological analyses of peripheral venous blood [13]. A positive microbiological culture is considered significant, if accidental contamination of the sample is not noted. The diagnosis of the coagulase-negative staphylococcus (CoNS) entails two positive microbiological cultures. For diagnosing pneumonia, it is necessary to confirm elevated body temperature as well as to have a radiologically confirmed finding of the lungs. Successful response to therapy entails the lowering of body temperature of $<37.5^{\circ} \mathrm{C}$, with clinically visible signs of improvement within the first 24 hours.

\section{Prophylaxis}

All of the patients received antiviral prophylaxis - acyclovir, 2 x $400 \mathrm{mg}$ p.o., 3 weeks, in the post-transplant period. As antifungal prophylaxis, fluconazole was administered, $150 \mathrm{mg}$ p.o. until +30 days (d) following transplantation.

\section{Statistical analysis}

Data was processed with the use of the SPSS 17.0 software package. Statistical analysis included the formation of a database, with the grouping and presentation of results in tables, according to the analyzed characteristics of the patients. Descriptive statistical parameters are presented as the arithmetic mean with dispersion 
živih bolesnika. Ishod lečenja se smatrao povoljnim ukoliko je postignuta kompletna remisija (KR) ili parcijalna remisija (PR). Preživljavanje bolesnika u odnosu na lečenje je računato Kaplan-Majerovom metodom. Kriterijum za statističku značajnost je bio $p<0,050$.

\section{REZULTATI}

Studijom je obuhvaćeno 80 pacijenata, prosečne sta-

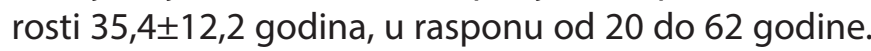
Grupu pacijenata sa multiplim mijelomom činilo je 50 osoba, 28 (56,0\%) muškaraca i $22(44,0 \%)$ žene. Prosečna starost u vreme dijagnostikovanja MM-a je bila $53,6 \pm 7$ godine, a prosečna starost u vreme ATMĆH-a je iznosila $55,8 \pm 6,8$ godine. (Tabela 1). Od sveukupnog broja ispitanika, 30 je bilo iz grupe obolelih od limfoma, i to $20(66,7 \%)$ žena i $10(33,3 \%)$ muškaraca. Obolelih od Hočkinovog limfoma je bilo 18 (60,0\%), a od nehočkinskih limfoma, 12 (40,0\%). Prosečna starost u vreme dijagnostikovanja limfoma je bila $35,4 \pm 12,1$ godina, a

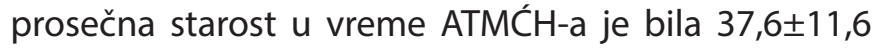
godina. $U$ vreme postavljanja dijagnoze, 9 pacijenata (30,0\%) je imalo I i II klinički stadijum (KS), dok je III-V KS imao 21 (70,0\%) pacijent. Demografske i kliničke karakteristike pacijenata sa HL-om i NHL-om navedene su u tabelama (Tabela 2).

$\mathrm{Na}$ osnovu Kaplan-Majerove analize, očekivano vreme preživljavanja nakon ATMĆH-a je iznosilo 34,5 meseci (Grafikon 1, Kliničke karakteristike bolesnika sa multiplim mijelomom).

Posmatrajući parametre engraftmenta kroz rekonstituciju limfocitne loze tj. ALC500_20 (apsolutni broj

Tabela 1. Kliničke karakteristike bolesnika sa multiplim mijelomom measurements (standard deviation - SD, standard error - $\mathrm{SE}$ ), the median, mode, and the distribution of relative frequencies. The Chi-square test was used for assessing the significance of the difference in the frequencies of the observed markers. Patient overall survival covered the period from the moment of diagnosis until the lethal outcome, or ending with data from December 2017, in living patients. The treatment outcome was considered favorable if complete remission (CR) or partial remission (PR) was achieved. Patient survival in relation to treatment was calculated with the Kaplan-Meier method. The criterion for statistical significance was $p<0.05$.

\section{RESULTS}

The study included 80 patients, whose average age was $35.4 \pm 12.2$ years, within the age range of $20-62$ years. The group of patients with multiple myeloma included 50 people, 28 (56\%) men and 22 (44.0\%) women. The average age at the time of the diagnosis of $M M$ was $53.6 \pm 7$ years, while the average age at the time of AHSCT was $55.6 \pm 6.8$ years. (Table 1). Of the total number of subjects, 30 belonged to the group of lymphoma patients, namely $20(66.7 \%)$ women and $10(33.3 \%)$ men. There were $18(60,0 \%)$ patients suffering from Hodgkin lymphoma, and 12 (40.0\%) patients suffering from non-Hodgkin lymphoma. The average age at the time of the diagnosis of lymphoma was $35.4 \pm 12.1$ years, while the average age at the time of AHSCT was $37.6 \pm 11.6$ years. At the time of diagnosis, $9(30.0 \%)$ patients were in clinical stage (CS) I and II, while 21 (70.0\%) were in CS III-V. The demographic and

Table 1. Clinical characteristics of patients with multiple myeloma

\begin{tabular}{lc}
\hline & Broj pacijenata (\%) / Number of patients (\%) \\
\hline Medijana starosti, godine / Median age, years & 54 \\
Opseg / Range & $39-63$ \\
\hline Pol / Gender & $28(56.0 \%)$ \\
$\quad$ Muškarci / Men & $22(44.0 \%$ \\
$\quad$ Žene / Women & $7(14.3 \%)$ \\
\hline Klinički stadijum I / Clinical stage I & $26(53.1 \%)$ \\
Klinički stadijum II / Clinical stage II & $16(32.7 \%)$ \\
Klinička stadijum III / Clinical stage III & $29(61.2 \%)$ \\
\hline Tip M komponente / Type ofM component & $11(22.5 \%)$ \\
IgG kappa / IgG kappa & $3(6.1 \%)$ \\
IgG lambda / IgG lambda & $5(11.9 \%)$ \\
IgA kappa / IgA kappa & \\
IgA lambda / IgA lambda & $(18.4 \%)$ \\
\hline Odgovor na terapiju: / Response to therapy & $32(65.3 \%)$ \\
KR / CR & $4(16.3 \%)$ \\
PR / PR & \\
VDPR / VGPR & \\
\hline
\end{tabular}


Milošević M. i sar.

Tabela 2. Kliničke karakteristike pacijenata sa Hočkinovim limfomom (HL) i nehočkinskim limfomima (NHL)
Table 2. Clinical features of patients with Hodgkin's lymphoma (HL) and nonHodgkin's lymphoma (NHL)

\begin{tabular}{|lcc|}
\hline & $H I / H L$ & NHL/NHL \\
\hline & Broj pacijenata (\%)/Number of patients (\%) & Broj pacijenata (\%) /Number of patients (\%) \\
\hline $\begin{array}{l}\text { Medijana starosti, godine / Median age, years } \\
\text { Opseg / Range }\end{array}$ & 27 & 41 \\
\hline Pol / Gender & & $20-62$ \\
\hline Muškarci / Male & $13(72.2 \%)$ & $7(58.3 \%)$ \\
\hline Žene / Female & $5(27.8 \%)$ & $5(41.7 \%)$ \\
\hline Klinički stadijum I-II / Clinical stage I-II & $7(38.9 \%)$ & $2(16.7 \%)$ \\
\hline Kliničkistadijum III-IV / Clinical stage III-IV & $11(61.1 \%)$ & $10(83.3 \%)$ \\
\hline B simptomi / Bsymptoms & & $5(41.7 \%)$ \\
\hline Da / Yes & $15(83.3 \%)$ & $7(58.3 \%)$ \\
\hline Ne / No & $3(16.7 \%)$ & $1(8.3 \%)$ \\
\hline Bulky tumorska masa / Bulky tumor mass & & $11(91.7 \%)$ \\
\hline Da / Yes & $9(50,0 \%)$ & \\
\hline Ne / No & $9(50,0 \%)$ & $8(66.7 \%)$ \\
\hline Terapijski odgovor / Therapeuticresponse & & $4(33.3 \%)$ \\
\hline CR+PR / CR+PR & $9(50,0 \%)$ & $9(50,0 \%)$ \\
\hline SD+PD / SD+PD & & \\
\hline
\end{tabular}

KR: kompletna remisija; PR: parcijalna remisija; SD: stabilna bolest; PD: progresivna bolest

limfocita $0,5 \times 10^{9} / \mathrm{L}$ na dan +20$)$, došli smo do zaključka da nije bilo statistički značajne povezanosti između navedenog parametra i preživljavanja $(p=0,547)$. Očekivano preživljavanje nakon ATMĆ $\mathrm{H}-\mathrm{a}$, kod pacijenata koji su dostigli ALC500_20 iznosilo je 34,7 meseci, a kod onih koji nisu 35,6 meseci. Uticaj dostizanja ANC500_11
CR: complete remission; PR: partial remission; SD: stable disease; PD: progressive disease

clinical characteristics of patients with $\mathrm{HL}$ and $\mathrm{NHL}$ are presented in the tables (Table 2).

Based on the Kaplan-Meier analysis, the expected length of survival following AHSCT was 34.5 months (Graph 1, Clinical characteristics of patients with multiple myeloma).

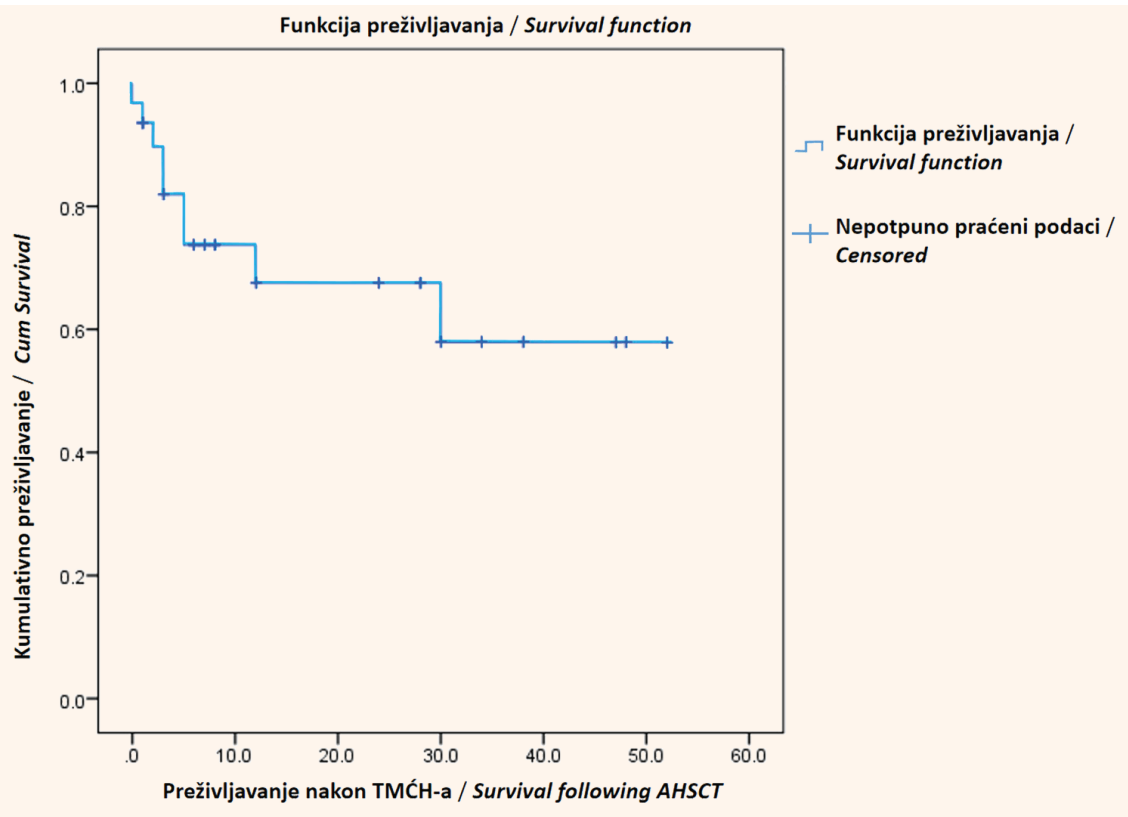

Grafikon 1. Ukupno preživljavanje nakon ATMĆH-a

Graph 1. Overall survival following AHSCT 
Tabela 3. Uticaj broja ALC500_20, ANC500_11, PLT20_13 na pojavu infekcije

\begin{tabular}{|c|c|c|c|c|}
\hline \multicolumn{2}{|c|}{ Infekcija / Infection } & \multirow{2}{*}{$\begin{array}{c}\text { Infekcija / Infection } \\
15(39.5 \%)\end{array}$} & \multirow{2}{*}{$\begin{array}{c}\text { Bez infekcije/ No Infection } \\
23(60.5 \%)\end{array}$} & \multirow{3}{*}{$\begin{array}{c}\mathbf{p} \\
0.424\end{array}$} \\
\hline \multirow{2}{*}{ ALC500_20 } & Dostignuta vrednost Achieved value & & & \\
\hline & Nedostignutavrednost / Value not achieved & $27(69.2 \%)$ & $12(30.8 \%)$ & \\
\hline \multirow{2}{*}{ ANC500_11 } & Dostignuta vrednost/ Achieved value & $18(39.1 \%)$ & $28(60.9 \%)$ & \multirow{2}{*}{0.356} \\
\hline & Nedostignutavrednost / Value not achieved & $8(28.6 \%)$ & $20(71.4 \%)$ & \\
\hline \multirow{2}{*}{ PLT20_13 } & Dostignuta vrednost / Achieved value & $22(37.3 \%)$ & $37(62.7 \%)$ & \multirow[b]{2}{*}{0.550} \\
\hline & Nedostignutavrednost / Value not achieved & $5(29.4 \%)$ & $12(70.6 \%)$ & \\
\hline
\end{tabular}

(apsolutni broj neutrofila $0,5 \times 10^{9} / \mathrm{L}$ na dan +11 ) na preživljavanje nakon ATMĆH-a takođe nije pokazalo statističku značajnost $(p=0,550)$. Ni rekonstitucija megakariocitne loze, tj. dostizanje PLT20_13 (broj trombocita $20 \times 10^{9} / \mathrm{L}$ na dan +13 ) nije statistički značajno uticalo na post-transplantaciono preživljavanje $(p=0,070)$.

Medijana broja primenjenih $\mathrm{CD}_{3} 4^{+}$matičnih ćelija u transplantatu iznosila je $6,7 \times 10^{6} \mathrm{~kg}$ telesne mase $(\mathrm{tm})$, (opseg: $2,3-15,5 \times 10^{6} / \mathrm{kg} \mathrm{tm}$ ). Nije potvrđena razlika između broja prisutnih $\mathrm{CD}^{+} 4^{+}$matičnih ćelija u transplantatu i rekonstitucije autologne hematopoeze tj. dostizanja vrednosti ALC500_20, ANC500_11 i PLT20_13. Povezanost rekonstitucije hematopoeze tj. dostizanja broja ALC500_20, ANC500_11 i PLT20_13 i pojave infekcije takođe nije imala statističku značajnost (Tabela 3).

Posmatranjem učestalosti infekcija, dobili smo podatke da su dominantni uzročnici infekcija bile bakterije, dok su gljivične i virusne infekcije bile retke. Nakon ATMĆH-a, 29 (36,3\%) pacijenata nije imalo bakterijsku infekciju, kod $25(31,3 \%)$ pacijenata je izolovan jedan uzročnik, a kod $26(32,5 \%)$ pacijenta je izolovano $\geq 2$ bakterijskih uzročnika. Od ukupnog broja pozitivnih bakterioloških kultura, GP bakterije su bili izazivači u $83,5 \%$ slučaja infekcije, što je čak pet puta veća učestalost u odnosu na GN bakterije. Najčešći GP uzročnici su bili koagulaza negativni staphylococcus (CoNS), pronađen u 37,0\% izolata, i Streptococcus a haemoliticus, pronađen u 12,4\% izolata. Ostali važniji GP uzročnici su dati u Grafikonu 2 (Grafikon 2). Među GN bakterijama najčešći izazivači su bili Escherichia coli, $62,5 \%$, Klebsiella spp., i Ralstonia pickettii, sa podjednakom učestalošću od 12,5\% (Grafikon 3). Gljivične infekcije su se javile kod $8(10,0 \%)$ pacijenata, i jedini izolovani uzročnik je bila Candida spp. Virusne infekcije su se ređe javljale, kod svega 5 (6,3\%) pacijenata, a izolovani su Herpes zoster virus (HZV) kod $3(3,8 \%)$ i H1N1 virus kod $2(2,5 \%)$ pacijenta. Nijedna parazitarna infekcija nije zabeležena.
Table 3. Influence of ALC500_20, ANC500_11, PLT20_13 on the occurrence of infection

Observing the engraftment parameters through the reconstitution of the lymphocyte lineage, i.e., ALC500_20 (absolute lymphocyte count $0,5 \times 10^{9} / \mathrm{L}$ per day +20 ), we have come to the conclusion that there was no statistically significant link between the said parameter and survival ( $p=0.547$ ). Expected survival following AHSCT, in patients who had reached ALC500_20 was 34.7 months, and in those patients who had not reached this value, it was 35.6 months. The influence of reaching ANC500_11 (absolute neutrophil count $0.5 \times 10^{9} /$ L per day +11 ) on survival following AHSCT also failed to demonstrate statistical significance $(p=0.550)$. The reconstitution of the megakaryocyte lineage, i.e., reaching PLT20_13 (platelet count $20 \times 10^{\%} / \mathrm{L}$ per day $+13)$ demonstrated no statistically significant impact on post-transplant survival ( $p=0.070$ ).

The median value of the number of $\mathrm{CD}_{3} 4^{+}$stem cells in the graft was $6.7 \times 10^{6} \mathrm{~kg}$ body mass (bm), (range: $2.3-15.5 \times 10^{6} / \mathrm{kg} \mathrm{bm}$ ). No difference was confirmed between the number of $\mathrm{CD}_{34}{ }^{+}$stem cells present in the graft and the reconstitution of autologous hematopoiesis, i.e., achieving the values of ALC500_20, ANC500_11, and PLT20_13. The link between hematopoiesis reconstitution, i.e., reaching the values ALC500_20, ANC500_11, and PLT20_13 and the development of infection also showed no statistical significance (Table 3).

Regarding the frequency of infections, we obtained data confirming that the dominant pathogens in the infections were bacteria, while fungal and viral infections were rare. Following AHSCT, 29 (36.3\%) patients did not have a bacterial infection, in $25(31.6 \%)$ patients, one pathogen was isolated, while in $26(32.5 \%)$ patients $\geq 2$ bacterial pathogens were isolated. Of the total number of positive bacterial cultures, GP bacteria were found in $83.5 \%$ cases of infection, which was as much as five time the frequency of GN bacteria. The most common GP pathogens were the coagulase-negative 
Milošević M. i sar.
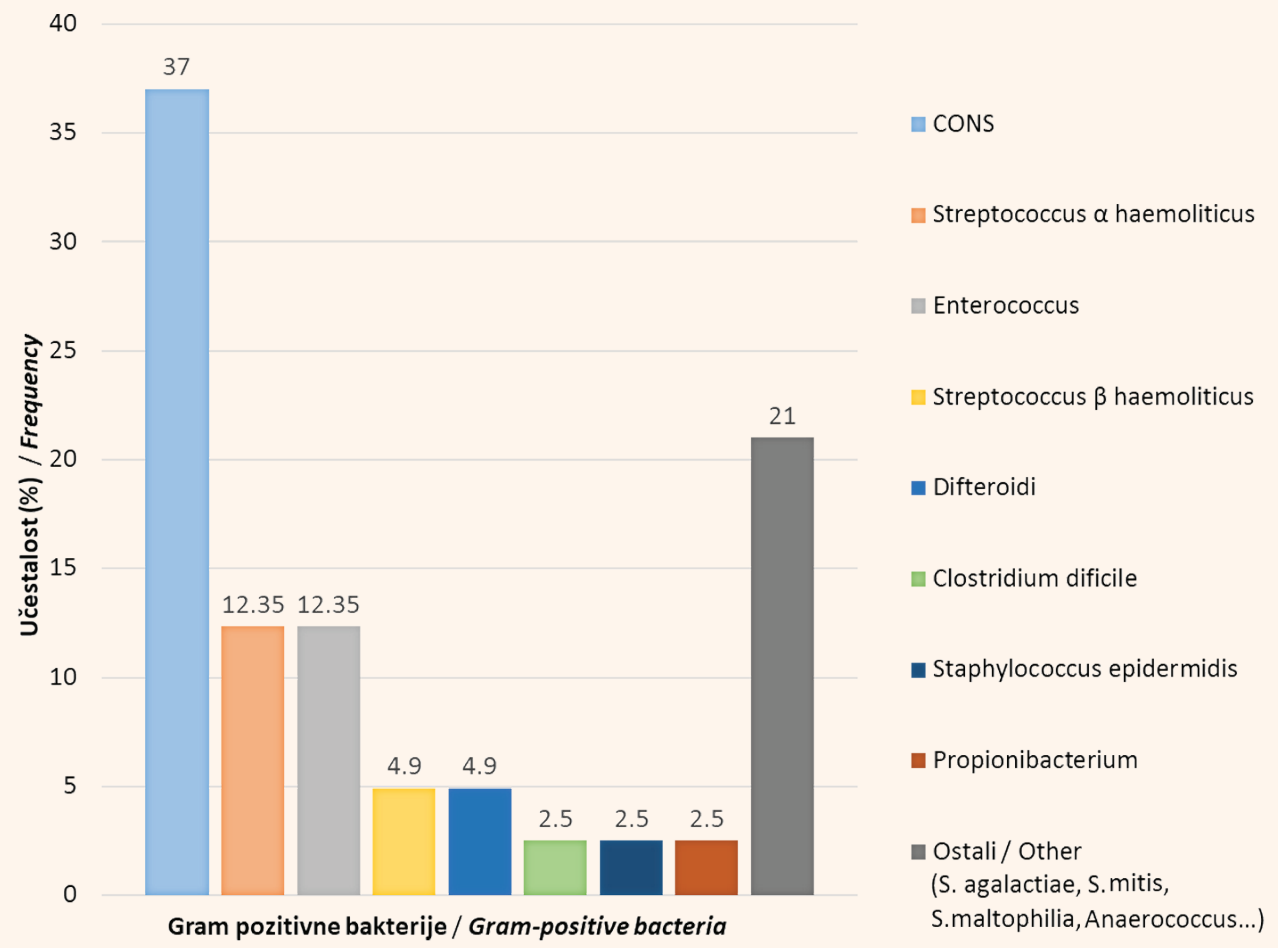

Grafikon 2. Učestalost gram pozitivnih bakterija kao uzročnika infekcija kod bolesnika lečenih autolognom transplantacijom do $\mathrm{d}+30$

Smrtni ishod je zabeležen kod 11 pacijenata, od čega je 9 pacijenata preminulo zbog razvoja infekcije. Šest pacijenata je preminulo zbog bakterijskih infekcija, 2 pacijenta obolela od limfoma su preminula kao posledica H1N1 virusne infekcije, usled razvoja respiratorne insuficijencije. Candida spp. sepsa je uzrokovala smrtni ishod kod jedne pacijentkinje obolele od
Graph 2. Frequency of gram-positive bacteria as the cause of infection in autologous transplant patients up to $d+30$

staphylococcus, found in $37.0 \%$ of isolates, and Streptococcus a haemoliticus, found in $12.4 \%$ of isolates. The remaining important GP pathogens are presented in Graph 2 (Graph 2). Amongst GN bacteria, the most common agents of infection were Escherichia coli, $62.5 \%$, Klebsiella spp., and Ralstonia pickettii, with the same frequency of occurrence of $12.5 \%$ (Graph 3). Fungal

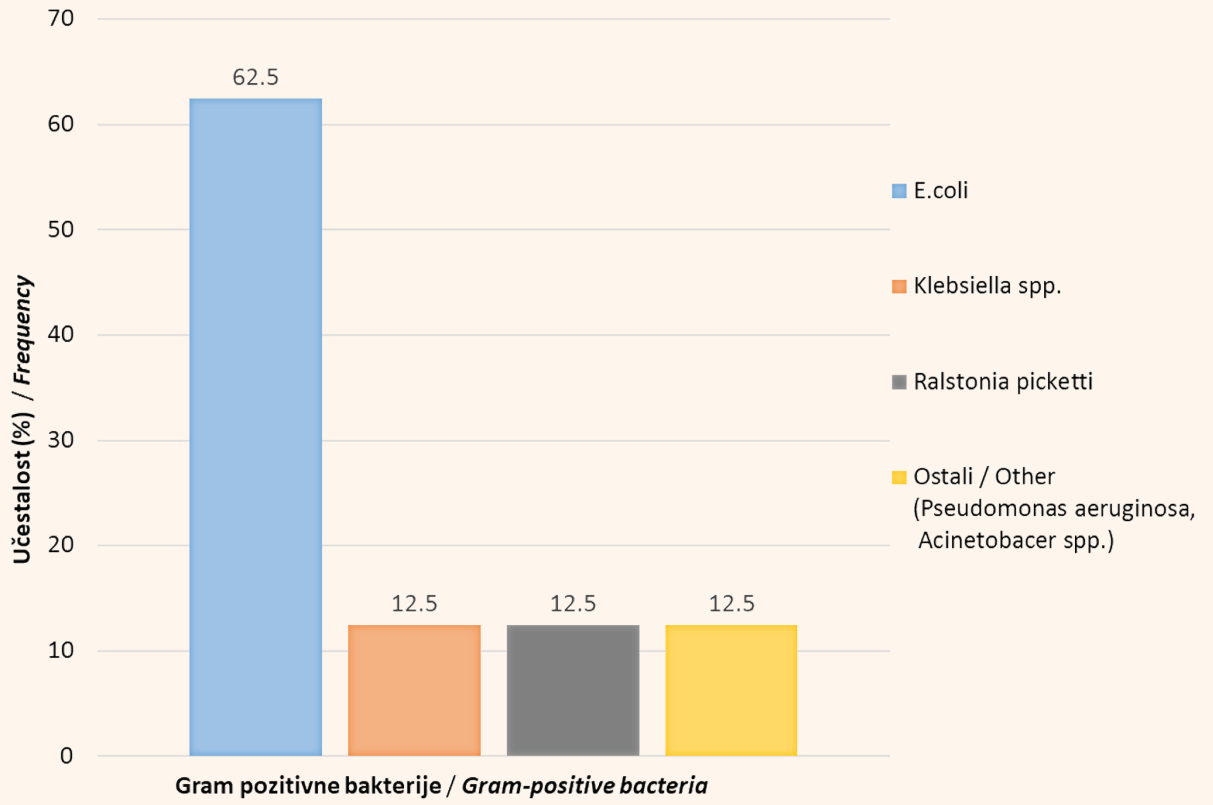

Grafikon 3. Učestalost gram negativnih bakterija kao uzročnika infekcija kod bolesnika lečenih autolognom transplantacijom do $\mathrm{d}+30$
Graph 3. Frequency of gram-negative bacteria as the cause of infection in autologous transplant patients, up to $d+30$ 
limfoma. Poređenjem vitalnog statusa kod pacijenata sa infekcijom dobili smo podatak o smrtnom ishodu kod $6(21,4 \%)$ osoba, dok je u grupi onih bez infekcije smrtni ishod nastao kod $5(10,0 \%)$ pacijenata. Hi-kvadrat test pokazao je da ne postoji statistički značajna razlika u odnosu na preživljavanje kod pacijenata sa i bez infekcije $(p=0,164)$.

\section{DISKUSIJA}

Naša studija je retrospektivno evaluirala razvoj infekcija nakon ATMĆH-a kod 80 odraslih pacijenata, od čega je ispitivano $50(62,5 \%)$ pacijenata sa MM-om i 30 $(37,5 \%)$ pacijenata sa limfomom.

Prevalencija GP infekcija je veća u odnosu na GN infekcije kod pacijenata sa solidnim tumorima, limfomima i MM-om [1,6-9] Bakterijemija se javila kod $63,8 \%$ naših pacijenata. Ova vrednost je za $\sim 10,0 \%$ manja u odnosu na incidenciju bakterijemije kod pacijenata sa limfomima i MM-om u istraživanju koje su sproveli Kolin i saradnici [12]. U njihovom uzorku, kod $63,6 \%$ pacijenata nije izolovana nijedna patogena bakterijska kultura, kod $26,6 \%$ pacijenata je izolovan samo jedan bakterijski uzročnik, a preostalih 9,8\% pacijenata je imalo $\geq 2$ bakterijskih izolata [12]. Niska učestalost bakterijskih infekcija $(21,3 \%)$ opisana je kod pacijenata sa MM-om, limfomima i solidnim tumorima [14].

Koagulaza negativni staphylococcus (CoNS) i Streptococcus a haemoliticus su bili najčešči GP uzročnici infekcije, dok su E. coli i Klebsiella spp. bili najčešći GN uzročnici bakterijemije u našoj grupi pacijenata, što korelira sa rezultatima drugih studija [15]. Clostridium difficile je uzročnik 10,0\% infekcija, što je pet puta češće nego u našem istraživanju [5]. Nakon visokodozne hemioterapije i ATMĆH-a, invazivne gljivične infekcije su izuzetno retke kod pacijenata i retko se mogu dokazati. Svi pacijenti u našoj grupi su dobili antigljivičnu profilaksu, međutim kod $8(10,0 \%)$ pacijenata je dokazana Candida spp. u brisu grla, ali uz pozitivan Candida mannan antigenski test, kod samo jednog pacijenta. U svojoj studiji, Gilbert i saradnici navode da se gljivice u krvi izoluju kod 4,0\% pacijenata koji nisu koristili antigljivičnu profilaksu [16]. Rajh i saradnici su opisali infekciju Candida glabrata-om, otpornom na azolne antimikotike [17]. Aspergillus flavus je izolovan kog jednog pacijenta u plućima [15]. Što se virusnih infekcija tiče, HZV infekcija se javila kod $28,0 \%$ ispitanika, što je u odnosu na naše rezultate sedam puta češće. Međutim, u ovom istraživanju, prosečno vreme reaktivacije virusa je bilo 5 meseci, odnosno, u 91,0\% slučajeva do reaktivacije je došlo u prvoj godini nakon transplantacije [18]. Antivirusna profilaksa aciklovirom je redukovala pojavu reaktivacije HSV-a. infections occurred in $8(10.0 \%)$ patients, and the only infectious agent isolated was Candida spp. Viral infections occurred less frequently, in only 5 (6.3\%) patients, and the Herpes zoster virus (HZV), in $3(3.8 \%)$ cases, and the H1N1 virus, in $2(2.5 \%)$ were isolated. No parasitic infections were registered.

The lethal outcome was registered in 11 patients, of whom 9 patients died due to the development of infection. Six patients died due to bacterial infection, 2 patients suffering from lymphoma died as the result of H1N1 viral infection, due to the development of respiratory insufficiency. Sepsis caused by Candida spp. was the cause of death in one female patient suffering from lymphoma. By comparing the vital status in patients with infection we obtained data on the lethal outcome in 6 (21.4\%) persons, while, in the group without infection, the lethal outcome was registered in $5(10.0 \%)$ patients. The Chi-square test showed no statistically significant difference, related to survival, between patients with and without infection $(p=0.164)$.

\section{DISCUSSION}

Our study retrospectively evaluated the development of infections following AHSCT, in 80 adult patients, of whom $50(62.5 \%)$ analyzed patients were suffering from MM while 30 (37.5\%) patients had lymphoma.

The prevalence of GP infections is higher than the prevalence of $\mathrm{GN}$ infections, in patients with solid tumors, lymphoma, and MM [1,6-9]. Bacteriemia occurred in $63.8 \%$ of our patients. This value is by $10,0 \%$ lower as compared to the bacteriemia incidence in patients with lymphoma and MM registered in a study by Collin et al. [12]. In their sample, in $63.6 \%$ of the patients no pathogen bacterial culture was isolated, in $26.6 \%$ of the patients, only one bacterial pathogen was isolated, while the remaining $9.8 \%$ of patients had $\geq 2$ bacterial isolates [12]. A low frequency of bacterial infections (21.3\%) was described in patients with MM, lymphoma and solid tumors [14].

Coagulase-negative staphylococcus (CONS) and Streptococcus a haemoliticus were the most common GP pathogens, while E. coli and Klebsiella spp. were the most common causes of bacteriemia in our group of patients, which correlates with the results of other studies [15]. Clostridium difficile is the cause of $10.0 \%$ of infections, which is five times more frequent than was the case in our study [5]. Following high-dose chemotherapy and AHSCT, invasive fungal infections are extremely rare in patients and can rarely be proven. All of the patients in our group received antifungal prophylaxis. However, in 8 (10.0\%) patients Candida spp. was confirmed with a throat swab, though a positive Candida mannan antigen test was noted in just one 
Ne postoji statistički značajna razlika u učestalosti infekcija kod MM-a u odnosu na limfome [17]. Ovi podaci su važni jer većina pacijenata pre ATMĆH-a prolazi kroz višestruke cikluse hemioterapije, koji su praćeni teškom neutropenijom u trajanju $>10$ dana. Prema kliničkim rezultatima koje navode Boudi i saradnici, trajanje neutropenije je glavni faktor rizika za nastanak infekcije, nezavisno od osnovne bolesti [19]. U istraživanju koje su sproveli Mosad i saradnici, nakon ATMĆH-a je postojala niska incidencija febrilnih komplikacija [20]. Sa druge strane, neka istraživanja potvrđuju pojavu febrilne neutropenije sa incidencijom od $100 \%$ u posttransplantacionom periodu [9].

Viver i saradnici su zabeležili stopu smrtnosti od $1,5 \%$, u grupi od 1.000 pacijenata podvrgnutim visokodoznoj hemioterapiji i ATMĆH-u, koja se direktno mogla pripisati infekcijama [21]. Kod pacijenata sa MM-om, limfomima i solidnim tumorima, snižen broj $\mathrm{CD} 4^{+}$matičnih ćelija u transplantatu nije povezan sa povećanim rizikom od infekcija nakon transplantacije [22]. Zbog malog broja CD34+ ćelija, pacijenti nakon autologne transplantacije mogu biti pod rizikom da razviju infekcije poput fatalne HSV pneumonije ili CMV retinitisa, kao i pacijenti nakon alogene transplantacije matičnih ćelija hematopoeze, a zbog odložene rekonstitucije hematopoeze [23].

Naša studija ima nekoliko ograničenja. Populacija pacijenata koju smo posmatrali bila je heterogena, a analiza je vršena retrospektivno. Samo mikrobiološki potvrđene infekcije su uključene $u$ ispitivanje. Analizirane su rane infekcije od 0 - 30 dana posle transplantacije.

\section{ZAKLJUČAK}

U našem istraživanju, pacijenti su, nakon ATMĆH-a, imali nizak rizik od smrtnog ishoda usled infekcije. Pojava infekcije nije korelirala sa brojem infundovanih $\mathrm{CD}_{3} 4^{+}$ćelija u transplantatu. Rekonstitucija autologne hematopoeze, tj. broj ALC500_20, ANC500_11 i PLT20_13 nije značajno uticao na pojavu infekcija. Bakterije su bile dominantni uzročnici infekcija, pri čemu su GP bakterije bile oko pet puta češće nego GN bakterije. Najčešći uzročnici iz grupe GP bakterija su bili CoNS i Streptococcus a haemoliticus. Najčešći GN uzročnici su bili Escherichia coli , Klebsiella spp. i Ralstonia. Incidencija infektivnih komplikacija nakon transplantacije se nije značajno razlikovala kod pacijenata sa limfomima i MM-om.

Primena profilaktičke terapije dovela je do smanjenja pojave virusnih i gljivičnih infekcija.

Sukob interesa: Nije prijavljen. patient. In their study, Gilbert et al. state that fungi was registered in the blood in $4.0 \%$ of patients who had not used antifungal prophylaxis [16]. Reich et al. described infection with Candida glabrata, resistant to azole antimycotics [17]. Aspergillus flavus was isolated in the lungs of one patient [15]. As to viral infections, $\mathrm{HZV}$ infection occurred in $28.0 \%$ of the subjects, which is seven times more frequent than was the case with our patients. However, in this study, the average time of reactivation of the virus was 5 months, i.e., in $91.0 \%$ of the cases, reactivation occurred in the first year following transplantation [18]. Antiviral prophylaxis with acyclovir has reduced the occurrence of the HSV virus.

There is no statistically significant difference in the occurrence of infection between MM and lymphoma [17]. This information is important as most patients, prior to AHSCT, go through multiple cycles of chemotherapy, which are followed by severe neutropenia lasting $>10$ days. According to the clinical results reported by Bodey et al., the duration of neutropenia is the main risk factor for the development of infection, independently of the underlying disease [19]. In a study by Mossad et al., a low incidence of febrile complications was registered [20]. On the other hand, some studies have confirmed the occurrence of febrile neutropenia with an incidence of $100 \%$ in the post-transplant period [9].

Weaver et al. registered a $1.5 \%$ mortality rate, in a group of 1,000 patients who had been subjected to high-dose chemotherapy and AHSCT, which could directly be attributed to infection [21]. In patients with MM, lymphoma, and solid tumors, a decreased number of $\mathrm{CD}_{3} 4^{+}$stem cells in the graft has not been connected to an increased risk of infection following transplantation [22]. Due to a small number of $\mathrm{CD}^{2} 4^{+}$cells, after autologous transplantation, patients may be at risk of developing similar infections, such as the fatal HSV pneumonia or CMV retinitis, to those occurring in patients after allogenic HSCT, as the result of delayed hematopoietic reconstitution [23].

Our study has several limitations. The population of patients analyzed was heterogenous, and the analysis was performed retrospectively. Only microbiologically confirmed infections were included in the study. Early infections, occurring 0 - 30 days following transplantation were analyzed.

\section{CONCLUSION}

In our study, after AHSCT, patients had a low risk of lethal outcome due to infection. The occurrence of infection did not correlate with the number of $\mathrm{CD} 34^{+}$ cells infused in the graft. The reconstitution of autologous hematopoiesis, i.e., the number of ALC500_20, ANC500_11, and PLT20_13, did not significantly affect 


\section{LITERATURA / REFERENCES}

1. Srinivasan A, Wang C, Srivastava DK, Burnette K, Shenep JL, Leung W, et al. Timeline, epidemiology, and risk factors for bacterial, fungal, and viral infections in children and adolescents after allogeneic hematopoietic stem cell transplantation. Biol Blood Marrow Transplant. 2013 Jan;19(1):94-101. doi: 10.1016/j.bbmt.2012.08.012.

2. Farge D, Labopin M, Tyndall A, Fassas A, Mancardi GL, Van Laar J, et al. Autologous hematopoietic stem cell transplantation for autoimmune diseases: an observational study on 12 years' experience from the European Group for Blood and Marrow Transplantation Working Party on Autoimmune Diseases. Haematologica. 2010 Feb;95(2):284-92. doi: 10.3324/haematol.2009.013458.

3. Burman J, Tolf A, Hägglund H, Askmark H. Autologous haematopoietic stem cell transplantation for neurological diseases. J Neurol Neurosurg Psychiatry. 2018 Feb;89(2):147-55. doi: 10.1136/jnnp-2017-316271.

4. Gratwohl A, Passweg J, Baldomero H, Hermans J. Blood and marrow transplantation activity in Europe 1997. European Group for Blood and Marrow Transplantation (EBMT). Bone Marrow Transplant. 1999 Aug;24(3):231-45. doi: 10.1038/sj.bmt.1701866.

5. Barton T, Collis T, Stadtmauer E, Schuster M. Infectious complications the year after autologous bone marrow transplantation or peripheral stem cell transplantation for treatment of breast cancer. Clin Infect Dis. 2001 Feb 1;32(3):391-5. doi: 10.1086/318491.

6. Auner HW, Zebisch A, Ofner P, Sill H, Linkesch W, Krause R. Evaluation of potential risk factors for early infectious complications after autologous peripheral blood stem cell transplantation in patients with lymphoproliferative diseases. Ann Hematol. 2005 Aug;84(8):532-7. doi: 10.1007/s00277005-1025-5.

7. Kolbe K, Domkin D, Derigs HG, Bhakdi S, Huber C, Aulitzky WE. Infectious complications during neutropenia subsequent to peripheral blood stem cell transplantation. Bone Marrow Transplant. 1997 Jan;19(2):143-7. doi: 10.1038/sj.bmt.1700621.

8. Salazar R, Solá C, Maroto P, Tabernero JM, Brunet J, Verger G, et al. Infectious complications in 126 patients treated with high-dose chemotherapy and autologous peripheral blood stem cell transplantation. Bone Marrow Transplant. 1999 Jan;23(1):27-33. doi: 10.1038/sj.bmt.1701520.

9. Nosanchuk JD, Sepkowitz KA, Pearse RN, White MH, Nimer SD, Armstrong D. Infectious complications of autologous bone marrow and peripheral stem cell transplantation for refractory leukemia and lymphoma. Bone Marrow Transplant. 1996 Aug;18(2):355-9.

10. Pagano L, Caira M, Nosari A, Van Lint MT, Candoni A, Offidani M, et al. Fungal infections in recipients of hematopoietic stem cell transplants: results of the SEIFEM B-2004 study--Sorveglianza Epidemiologica Infezioni Fungine Nelle Emopatie Maligne. Clin Infect Dis. 2007 Nov 1;45(9):1161-70. doi: $10.1086 / 522189$.

11. Kontoyiannis DP, Marr KA, Park BJ, Alexander BD, Anaissie EJ, Walsh TJ, et al. Prospective surveillance for invasive fungal infections in hematopoietic stem cell transplant recipients, 2001-2006: overview of the Transplant-Associated Infection Surveillance Network (TRANSNET) Database. Clin Infect Dis. 2010 Apr 15;50(8):1091-100. doi: 10.1086/651263.

12. Collin BA, Leather HL, Wingard JR, Ramphal R. Evolution, incidence, and susceptibility of bacterial bloodstream isolates from 519 bone marrow transplant patients. Clin Infect Dis. 2001 0ct 1;33(7):947-53. doi: 10.1086/322604.

13. Hughes WT, Armstrong D, Bodey GP, Brown AE, Edwards JE, Feld R, et al. 1997 guidelines for the use of antimicrobial agents in neutropenic patients with unexplained fever. Infectious Diseases Society of America. Clin Infect Dis. 1997 Sep;25(3):551-73. doi: 10.1086/513764. the occurrence of infection. Bacteria were the predominant cause of infection, with GP bacteria being around five times more common than GN bacteria. The most common pathogens from the GP group of bacteria were CoNS and Streptococcus a haemoliticus. The most common GN pathogens were Escherichia coli, Klebsiella spp., and Ralstonia. The incidence of infectious complications following transplantation did not significantly differ between patients with lymphoma and MM patients.

The application of prophylactic therapy has led to a decrease in the occurrence of viral and fungal infections.

Conflict of interest: None declared.

14. Mossad SB, Longworth DL, Goormastic M, Serkey JM, Keys TF, Bolwell BJ. Early infectious complications in autologous bone marrow transplantation: a review of 219 patients. Bone Marrow Transplant. 1996 Aug;18(2):265-71.

15. Srinivasan A, MCLaughlin L, Wang C, Srivastava DK, Shook DR, Leung W, et al. Early infections after autologous hematopoietic stem cell transplantation in children and adolescents: the St. Jude experience. Transpl Infect Dis. 2014 Feb;16(1):90-7. doi: 10.1111/tid.12165.

16. Gilbert C, Meisenberg B, Vredenburgh J, Ross M, Hussein A, Perfect J, et al. Sequential prophylactic oral and empiric once-daily parenteral antibiotics for neutropenia and fever after high-dose chemotherapy and autologous bone marrow support. J Clin Oncol. 1994 May;12(5):1005-11. doi: 10.1200/ JC0.1994.12.5.1005.

17. Reich G, Mapara MY, Reichardt P, Dörken B, Maschmeyer G. Infectious complications after high-dose chemotherapy and autologous stem cell transplantation: comparison between patients with lymphoma or multiple myeloma and patients with solid tumors. Bone Marrow Transplant. 2001 Mar;27(5):525-9. doi: 10.1038/sj.bmt.1702822.

18. Schuchter LM, Wingard JR, Piantadosi S, Burns WH, Santos GW, Saral R. Herpes zoster infection after autologous bone marrow transplantation. Blood. 1989 Sep;74(4):1424-7.

19. Bodey GP, Buckley M, Sathe YS, Freireich EJ. Quantitative relationships between circulating leukocytes and infection in patients with acute leukemia. Ann Intern Med. 1966 Feb;64(2):328-40. doi: 10.7326/0003-4819-64-2-328.

20. Mossad SB, Longworth DL, Goormastic M, Serkey JM, Keys TF, Bolwell BJ. Early infectious complications in autologous bone marrow transplantation: a review of 219 patients. Bone Marrow Transplant. 1996 Aug;18(2):265-71.

21. Weaver $C H$, Schwartzberg LS, Hainsworth J, Greco FA, Li W, Buckner CD, et al. Treatment-related mortality in 1000 consecutive patients receiving highdose chemotherapy and peripheral blood progenitor cell transplantation in community cancer centers. Bone Marrow Transplant. 1997 Apr;19(7):671-8. doi: 10.1038/sj.bmt.1700713.

22. Frère $P$, Pereira $M$, Fillet $G$, Beguin $Y$. Infections after CD34-selected or unmanipulated autologous hematopoietic stem cell transplantation. Eur J Haematol. 2006 Feb;76(2):102-8. doi: 10.1111/j.1600-0609.2005.00569.x.

23. Miyamoto T, Gondo H, Miyoshi Y, Shigematsu H, Minematsu T, Takenaka K, et al. Early viral complications following CD34-selected autologous peripheral blood stem cell transplantation for non-Hodgkin's lymphoma. Br J Haematol. 1998 Feb;100(2):348-50. doi: 10.1046/j.1365-2141.1998.00572.x. 